\title{
Water Quality Characteristics at the Estuary of Korle Lagoon in Ghana
}

\author{
A. Y. Karikari*, K. A. Asante and C. A. Biney \\ CSIR-Water Research Institute, P. O. Box AH 38, Achimota, Ghana. \\ * Corresponding author
}

\begin{abstract}
The Korle lagoon is a major run-off water receptacle and outlet from the city of Accra into the Gulf of Guinea. Uncontrolled discharges of domestic wastes and industrial effluents as well as raw sewage (which are washed into the lagoon during high tides), have led to its environment being seriously degraded. Physico-chemical and bacteriological studies were conducted to measure the concentration of pollutants at the entrance of the Korle lagoon, from the offshore of the lagoon and from the raw sewage discharged onto the beach at neap and spring tides. Physical characteristics of the lagoon waters, such as $p \mathrm{H}$ and temperature, for the two tides did not show any large variations and were fairly comparable. Salinity, suspended solids and conductivity, however, varied significantly with tidal changes. Dissolved oxygen was extremely low at low tide as a result of large quantities of waste materials from domestic and industrial activities which reach the lagoon. This was also evidenced in high biochemical oxygen demand (BOD) as well as high faecal coliforms during neap tide. Changes in the concentrations of nutrients occurred with changes in tide; these being high, especially at high tide when sewage is back-washed into the lagoon. The study indicated that the entrance of the Korle lagoon to the sea and the adjacent sewage outfall area were polluted and not suitable for primary or secondary contact due to the occurrence of large numbers of coliform bacterial. However, the offshore area showed good water quality.
\end{abstract}

\section{Introduction}

The Korle lagoon is a major run-off water receptacle and a point source of pollution into the Gulf of Guinea. The lagoon which, otherwise, would have been a scenic landscape and supported socio-economic activities in the Metropolis, receives uncontrolled discharges of domestic and industrial wastes as well as raw sewage which is back-washed from the sea into the lagoon during high tide. The siltation of the lagoon has reduced its floodwater carrying capacity with the result that serious flooding occurs in the city during the rainy season.

In the past $(1963,1973,1986)$, there have been several reported incidents of flooding (Daily Graphic, 10th March 1995) resulting in the loss of lives and property. The shallowness and grossly polluted state render it unsuitable for navigation or recreation or even fishing. The combined effects of the above have adversely affected the lagoon, which, according to historical evidence, supported commercial fisheries with attendant socio-economic activities of the communities living around the lagoon up to the 1960's.

As part of strategies to restore the lagoon and also solve some of the environmental problems in the Accra Metropolis, the Overseas Development Administration (now Department for International Development) of the United Kingdom agreed to assist the Government of Ghana to build a sewage treatment plant to treat waste waters from the central sewerage system and from other parts of Accra.

As part of the environmental impact assessment of the Accra waste project, a water quality survey was conducted by measuring the concentrations of selected pollutants at the entrance to the Korle lagoon from offshore of the lagoon, and the raw sewage discharge onto the beach adjacent to the lagoon. This paper reports the findings of the survey.

\section{Material and methods}


The Korle lagoon (Fig. 1) is located to the south-west of the central business district of Accra. It is the major basin into which the greater proportion of the floodwaters of metropolitan Accra flow before entering the sea. The lagoon covers a total surface area of about $0.6 \mathrm{~km}^{2}$ and drains a total catchment area of about $400 \mathrm{~km}^{2}$. From its opening in the south, the lagoon stretches northwards inland for about $2.8 \mathrm{~km}$, with varying widths between $179 \mathrm{~m}$ at the north-west crosssection and $349 \mathrm{~m}$ at the widest cross-section (Nai, 1994).

The major inlets into the lagoon are the Odaw river and two major drains on its eastern and western sections. The major tributary of the Odaw river is the River Onyasia, which drains the northern parts of Accra including Haatso, Papao and Agbogba.

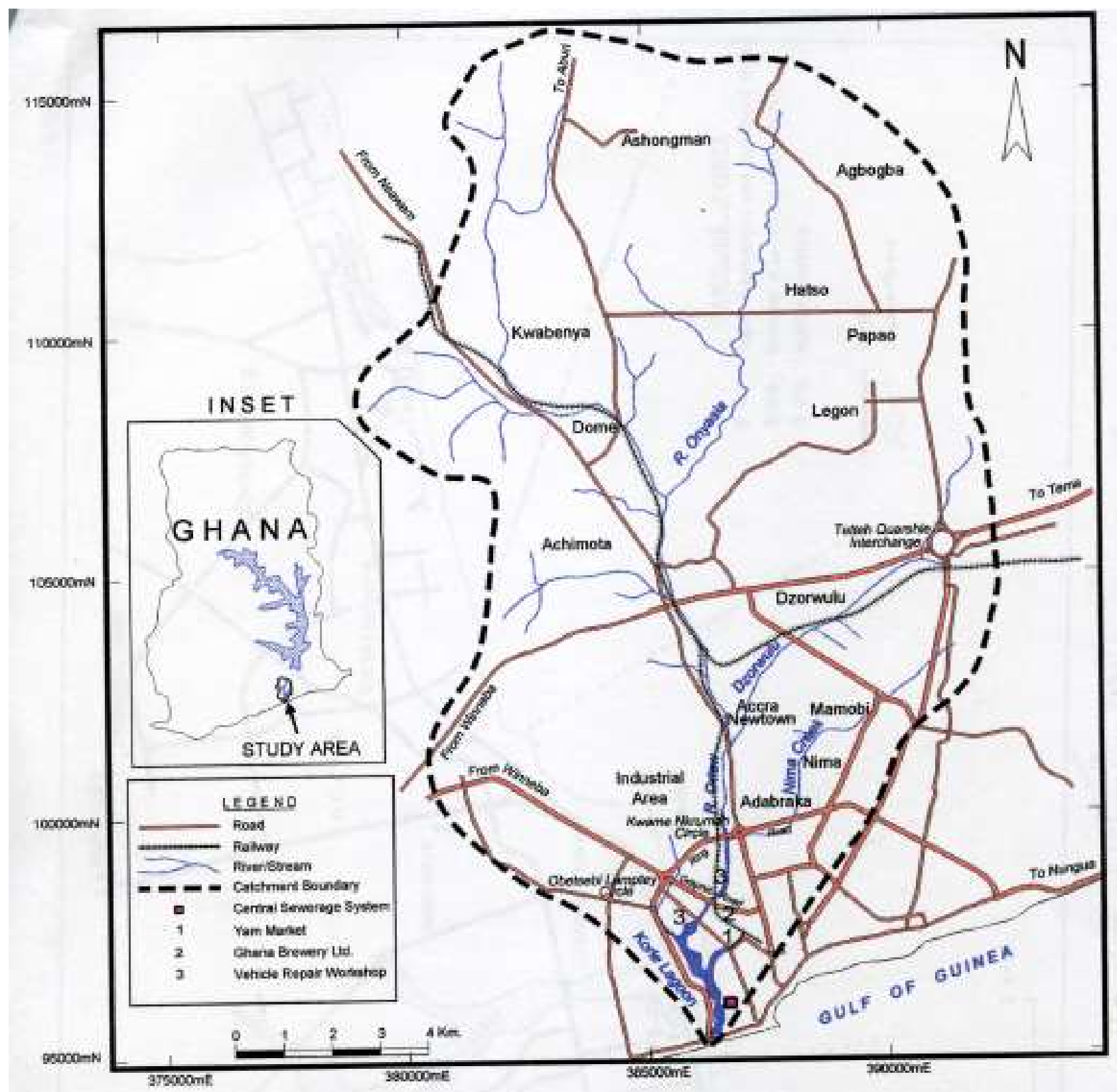

Fig. 1. Drainage Map of Korle lagoon catchment area 
The Odaw river drains Dome, Legon, Achimota, Ring Road Industrial Area and the high density low income areas of Nima, Maamobi and Accra Newtown. The catch-ment area of the Odaw river is, thus, densely populated and has a large concentration of industries including Ghana Breweries Limited, several textile factories and vehicle repair workshops.

The eastern channel drains the eastern and central parts of Accra including areas around Accra Brewery Limited. Several light industries are situated in this area. The western channel drains the western parts of Accra including Kaneshie and Korle-Bu Hospital. These areas are mainly residential although there is an array of vehicle repair shops, a common feature of the Accra metropolis. These major channels are interconnected by a network of medium and smaller-sized drains, which are mostly uncovered and are, therefore, used for the disposal of untreated domestic and industrial effluents, which are ultimately flushed into the lagoon by floodwaters.

The lagoon empties into the sea near Korle Gonno (Fig. 1) through a rubble-mould outfall of width $22 \mathrm{~m}$. This southern-most section is tidal. The lagoon was dredged between 1961 and 1963. Inadequate attempts were made in 1976 to deepen the tidal sections but, subsequently, its capacity has been seriously reduced by siltation and also by the proliferation of mangrove vegetation of the species Rhizophora (deGraft-Johnson, 1991; Amoah et al., 1998). Siltation of the lagoon is, to a large extent, caused by flood waters, which erode the commonly unpaved areas in the catchment, and transport the silt into the lagoon. About $57 \%$ of the population of Accra live in the catchment of the lagoon (Amuzu, 1995).

The Korle lagoon is associated with intensive land use and waste disposal. The banks of the lagoon are used as solid waste landfill site. Abandoned vehicles and old machinery are disposed in open spaces around the Abossey Okai road. Small garages and workshops are located in the catchment of the lagoon. The location of the yam market on the banks of the lagoon adds to the pollution load. Treatment plant for septic tank effluent is sited about $200 \mathrm{~m}$ west of the mouth of the lagoon. Adjacent to the mouth of the lagoon, on the east side, is located a sewage outfall. Although no figures are available, a good percentage of the people have no access to toilet facilities and, as such, resort to open defaecation along the banks of the lagoon and along the beach. A piggery is located close to the mouth of the lagoon. Beach seining and other fishing activities take place at the mouth of the lagoon and within $500 \mathrm{~m}$ offshore. Currently, there are attempts to rehabilitate the lagoon through Korle Lagoon Ecological Restoration Project (KLERP).

\section{Sampling sites}

The field studies at various sites were carried out on 7th and 14th April 1997, which corresponded to spring and neap tides, respectively. Spring tides have higher high tides and lower low tides, whereas neap tides have lower high tides and higher low tides. The time difference between spring tide and neap tide is normally 7 days. Samples were taken from the mouth of the Korle lagoon, offshore and at the sewage outfall (Fig. 2). Surface water samples were collected under the old Winneba road bridge every $2 \mathrm{~h}$ during two 12-h tidal cycles (site 5TQ). Offshore surface waters were sampled once at two sites (7-WQ and 9-WQ), $500 \mathrm{~m}$ offshore and $2 \mathrm{~km}$ apart. The raw sewage flow over the beach was sampled at 4-h intervals for $24 \mathrm{~h}$ (site 6-DQ). 


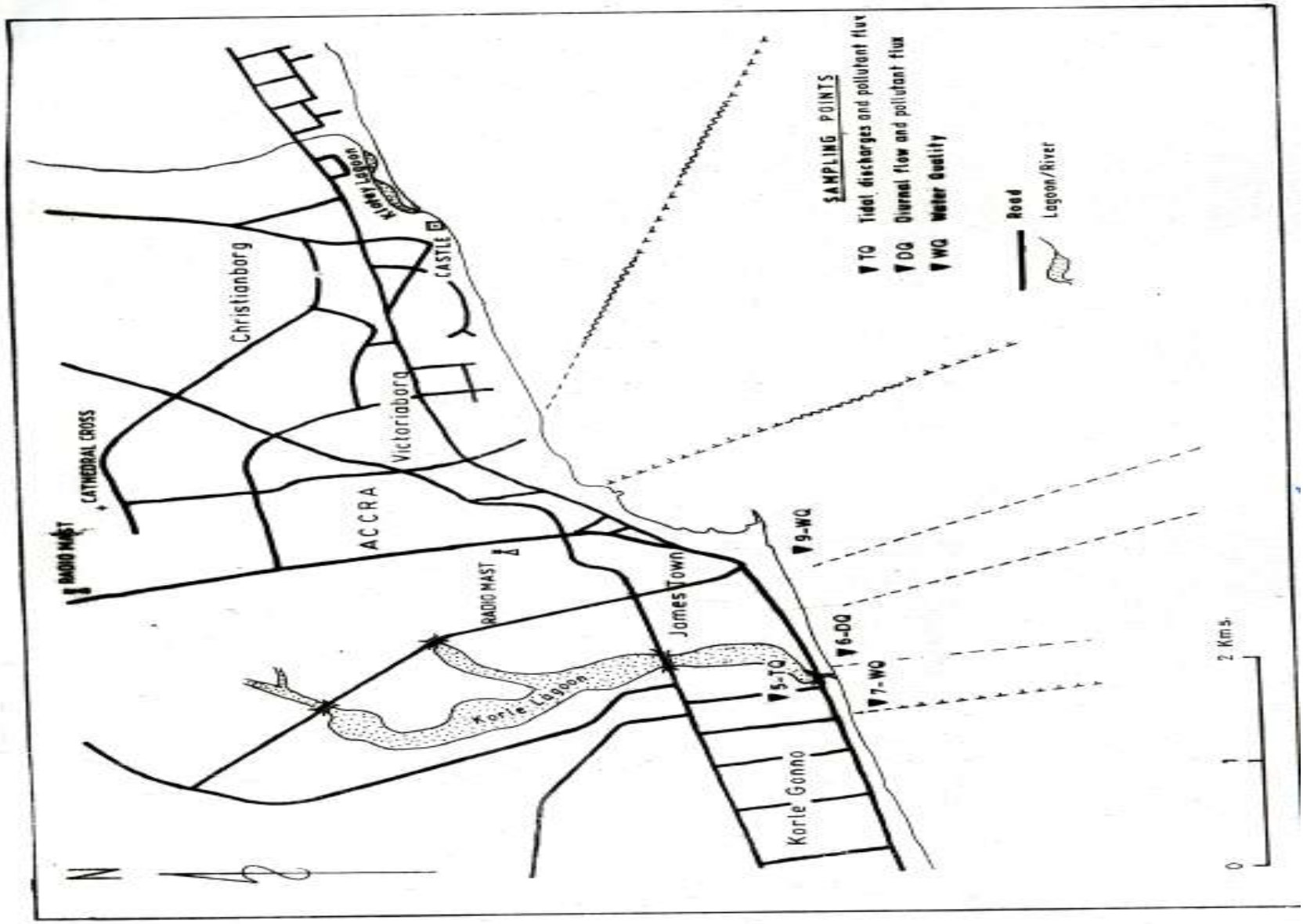

Fig. 2. Location of sampling sites

Samples for physico-chemical analyses were collected into clean 1-litre plastic bottles. Temperature, conductivity, salinity and $p \mathrm{H}$ were measured in situ using a Horiba $\mathrm{V}-10$ meter with combined electrodes. Dissolved oxygen (DO) was measured using a DO meter, YSI Model 5I B. Samples for bio-chemical oxygen demand (BOD) determina-tions were collected in dark bottles and stored at $20^{\circ} \mathrm{C}$ for 5 days in an incubator before the remaining DO was determined. Samples for bacteriolo-gical analyses were collected into sterilized plain glass bottles. Field and laboratory determinations were according to the standard methods for the examination of water and waste water (American Public Health Association, 1989) and the World Health Organization, Global Environmental Monitoring System/Water Operational Guide, 1987.

The methods employed for the analyses are summarised as follows:

1.Suspended solids (SS): membrane filtration, followed by drying at $105{ }^{\circ} \mathrm{C}$ and weighing; 2 . Total phosphate: sulphuric acid/persulphate digestion followed by reaction with ammonium molybdate and ascorbic acid to form a blue molybdate complex, whose intensity was measured at $880 \mathrm{~nm}$ using UV spectrophotometer; 3. Kjeldahlnitrogen: acid digestion in the presence of selenium catalyst followed by determination of ammonia-nitrogen; 4. Ammonianitrogen: direct Nesslerisation and spectrophotometric determination; 5. Nitratenitrogen: reaction with Brucinesulfanilic acid, which produced a yellow colour and measured spectrophoto-metrically at 410 $\mathrm{nm}$; 6. Total coliforms: membrane filtration using lauryl sulphate broth and incubation at $37^{\circ} \mathrm{C}$ for $16 \mathrm{~h}$; 7. faecal coliforms: membrane filtration using lauryl sulphate broth and incubation at 44 ${ }^{\circ} \mathrm{C}$ for $16 \mathrm{~h}$; 8 . BOD: incubation at $20^{\circ} \mathrm{C}$ for 5 days followed by iodometric titration. 


\section{Results and discussion}

Tables 1 and 2 and Fig. 3-8 summarize the results of physical, chemical and bacterio-logical analyses. Where possible, these are presented alongside natural background levels for tropical coastal waters (Riley \& Chester, 1971; Burton \& Liss, 1976).

TABLE 1

Physical Characteristics (Spring tide)

Sample

location

Korle lagoon (Site 5 -TQ)

Korle lagoon (Site 5 -TQ)

Korle lagoon (Site 5 -TQ)

Korle lagoon (Site 5 -TQ)

Korle lagoon (Site 5 -TQ)

Korle lagoon (Site 5 -TQ)

Mean

Sewage discharge (Site 6-DQ)

Sewage discharge (Site 6-DQ)

Sewage discharge (Site 6-DQ)

Sewage discharge (Site 6-DQ)

Sewage discharge (Site 6-DQ)

Sewage discharge (Site 6-DQ)

\section{Mean}

Offshore (Site 7-WQ)

Offshore (Site 9-WQ)

Background

$\begin{array}{rrrrrrr}\begin{array}{l}\text { Time } \\ (G M T)\end{array} & \begin{array}{l}\text { Temp. } \\ \left({ }^{\circ} \mathrm{C}\right)\end{array} & \mathrm{p} H & \begin{array}{r}\text { Cond. } \\ (\mu \mathrm{S} / \mathrm{cm})\end{array} & \begin{array}{l}S(\% \circ) \\ (\mathrm{ppt})\end{array} & \begin{array}{l}\text { DO } \\ \left(\mathrm{mgl} \mathrm{l}^{-1}\right)\end{array} & \begin{array}{r}\text { SS } \\ \left(\mathrm{mgl}^{-1}\right)\end{array} \\ 1130 & 33.0 & 7.2 & 32000 & 20.0 & 0.20 & 195 \\ 1330 & 32.0 & 7.8 & 57000 & 38.0 & 5.00 & 260 \\ 1530 & 31.0 & 7.7 & 57000 & 30.0 & 5.00 & 220 \\ 1730 & 31.0 & 7.8 & 57000 & 38.0 & 5.00 & 225 \\ 1930 & 33.0 & 7.3 & 51000 & 34.0 & 0.20 & 230 \\ 2130 & 31.0 & 7.1 & 32000 & 20.0 & 0.30 & 205 \\ & \mathbf{3 1 . 8} & \mathbf{7 . 5} & \mathbf{4 7 6 6 7} & \mathbf{3 0 . 0} & \mathbf{2 . 6 2} & \mathbf{2 2 3} \\ 600 & 32.0 & 6.1 & 2500 & 1.0 & 0.80 & 1260 \\ 1000 & 33.0 & 6.2 & 2000 & 1.0 & 0.40 & 340 \\ 1400 & 34.0 & 6.1 & 2300 & 1.0 & 0.40 & 290 \\ 1800 & 34.0 & 6.4 & 2700 & 1.0 & 0.40 & 280 \\ 2400 & 33.0 & 7.3 & 1800 & 1.0 & 0.80 & 500 \\ 200 & 33.0 & 6.5 & 2300 & 1.0 & 1.00 & 286 \\ & \mathbf{3 3 . 2} & \mathbf{6 . 4} & \mathbf{2 2 6 5} & \mathbf{1 . 0} & \mathbf{0 . 6 0} & \mathbf{4 9 3} \\ 1045 & 28.2 & - & - & 35.4 & 6.47 & 175 \\ 1330 & 28.6 & - & - & 34.6 & 6.14 & 220 \\ - & 26-32 & 7-8 & - & 35 & 7 & -\end{array}$

TABLE 2

Physical Characteristics (Neap tide)

$\begin{aligned} & \text { Sample } \\ & \text { location }\end{aligned}$
Korle lagoon (Site 5-TQ)
Korle lagoon (Site 5-TQ)
Korle lagoon (Site 5-TQ)
Korle lagoon (Site 5-TQ)
Korle lagoon (Site 5-TQ)
Korle lagoon (Site 5-TQ)
Mean
Sewage discharge (Site 6-DQ)
Sewage discharge (Site 6-DQ)
Sewage discharge (Site 6-DQ)
Sewage discharge (Site 6-DQ)
Sewage discharge (Site 6-DQ)
Sewage discharge (Site 6-DQ)
Mean
Offshore (Site 7-WQ)
Offshore (Site 7-WQ)
Background

$\begin{array}{ccccccc}\begin{array}{c}\text { Time } \\ (\text { GMT })\end{array} & \begin{array}{c}\text { Temp. } \\ \left({ }^{\circ} \mathrm{C}\right)\end{array} & \mathrm{pH} & \begin{array}{c}\text { Cond. } \\ (\mu \mathrm{S} / \mathrm{cm})\end{array} & \begin{array}{c}S(\%) \\ (\mathrm{ppt})\end{array} & \begin{array}{c}\text { DO } \\ \left(\mathrm{mgl}^{-1}\right)\end{array} & \begin{array}{c}S S \\ \left(\mathrm{mgl} \mathrm{l}^{-1}\right)\end{array} \\ 0900 & 30.5 & 7.6 & 48600 & 31.8 & 4.40 & 240 \\ 1100 & 35.3 & 7.4 & 15800 & 9.10 & 0.60 & 115 \\ 1300 & 34.1 & 7.3 & 7620 & 4.10 & 0.50 & 85 \\ 1500 & 34.4 & 7.3 & 9900 & 5.50 & 0.85 & 90 \\ 1700 & 33.0 & 7.3 & 10900 & 6.10 & 1.00 & 80 \\ 1900 & 30.5 & 7.5 & 51500 & 33.8 & 4.20 & 230 \\ & \mathbf{3 3 . 0} & \mathbf{7 . 4} & \mathbf{2 4 1 0 0} & \mathbf{1 5 . 1} & \mathbf{1 . 9 3} & \mathbf{1 4 0} \\ 0900 & 32.8 & 6.8 & 2230 & 1.00 & 0.40 & 238 \\ 1300 & 33.5 & 6.8 & 1970 & 0.90 & 0.30 & 300 \\ 1700 & 31.7 & 6.7 & 2370 & 1.10 & 0.20 & 380 \\ 2100 & 30.1 & 6.7 & 2060 & 1.00 & 1.00 & 500 \\ 0100 & 31.5 & 6.6 & 2190 & 1.00 & 1.20 & 340 \\ 0500 & 31.2 & 6.6 & 2280 & 1.10 & 1.40 & 300 \\ & \mathbf{3 1 . 8} & \mathbf{6 . 7} & \mathbf{2 1 8 0} & \mathbf{1 . 0 0} & \mathbf{0 . 7 5} & \mathbf{3 4 3} \\ 1530 & 29.8 & - & - & 34.9 & 6.02 & 175 \\ - & 28.5 & - & - & 33.9 & 6.03 & 195 \\ - & 26-32 & 7-8 & - & 35 & 7 & -\end{array}$




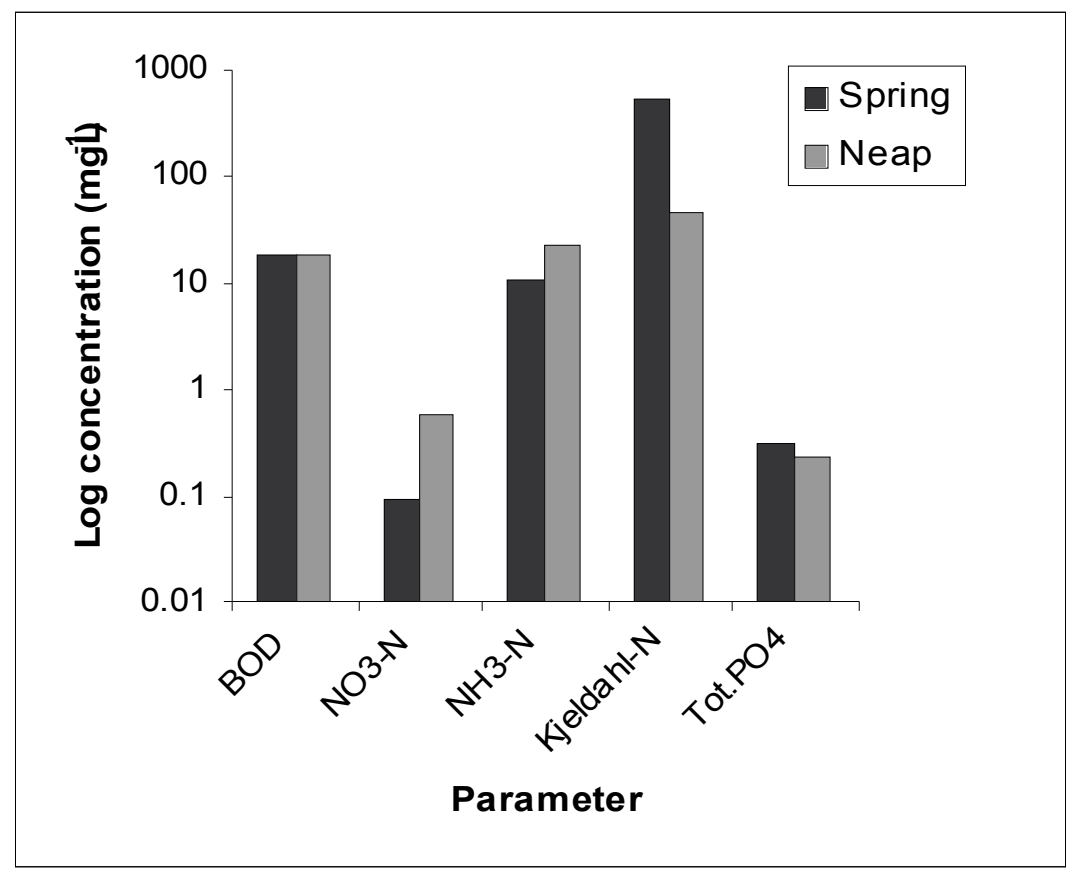

Fig. 3. Mean BOD and nutrient levels for spring and neap tides at site 5-TQ (Lagoon entrance)

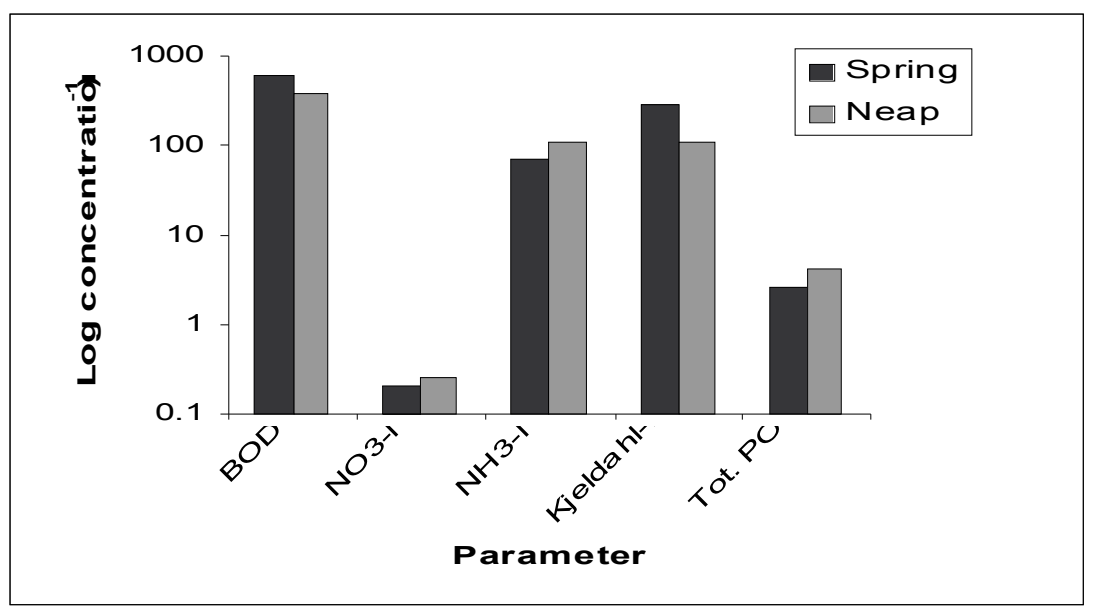

Fig. 4. Mean BOD and nutrient levels for spring and neap tides at site 6-DQ (Sewage outfall) 


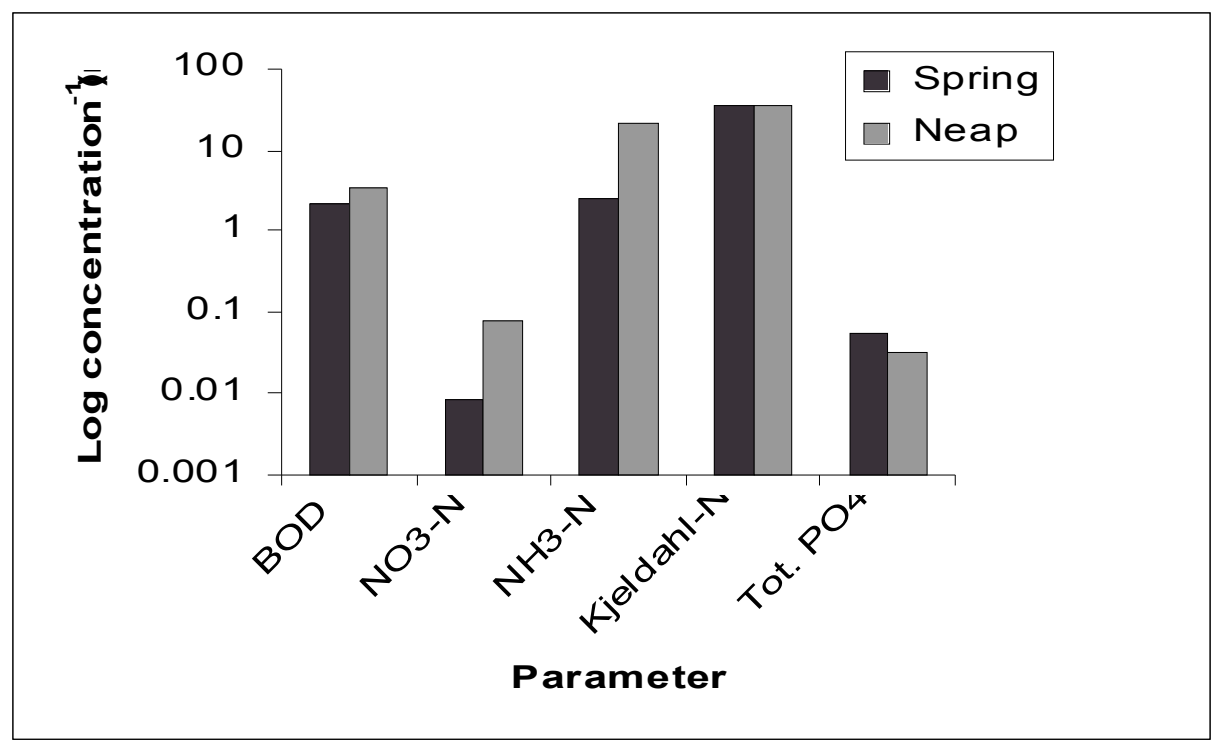

Fig. 5. BOD and nutrient levels for spring and neap tides at site 7-WQ (Offshore)

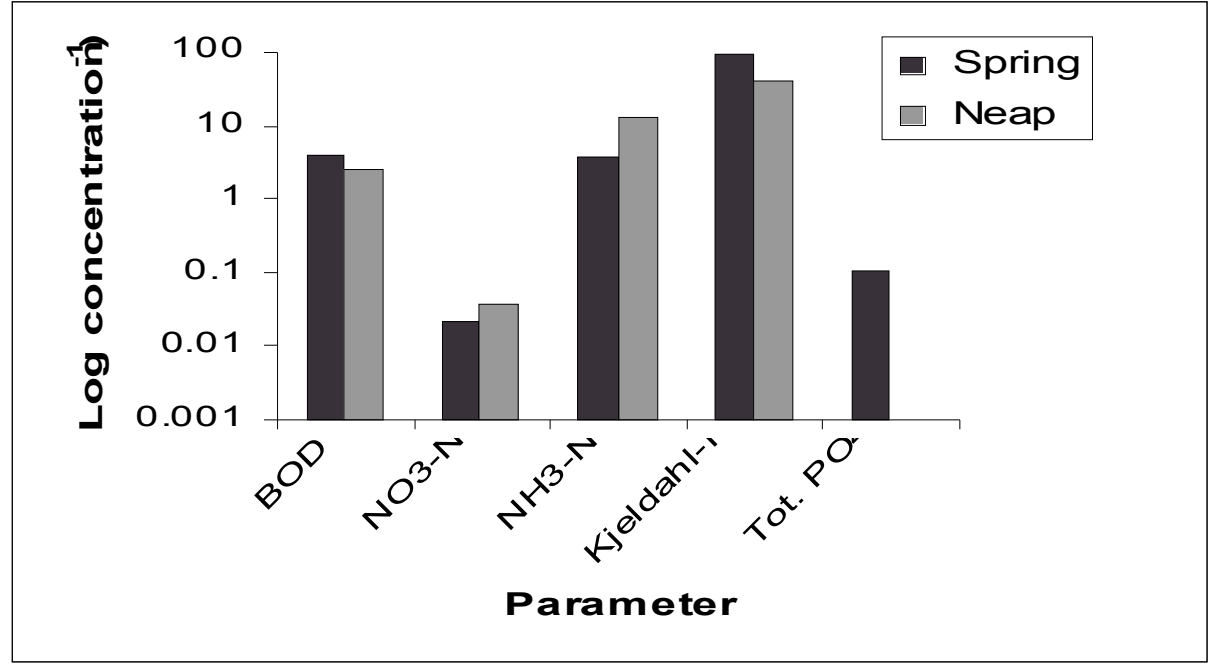

Fig. 6. BOD and nutrient levels for spring and neap tides at site 9-WQ (Offshore)

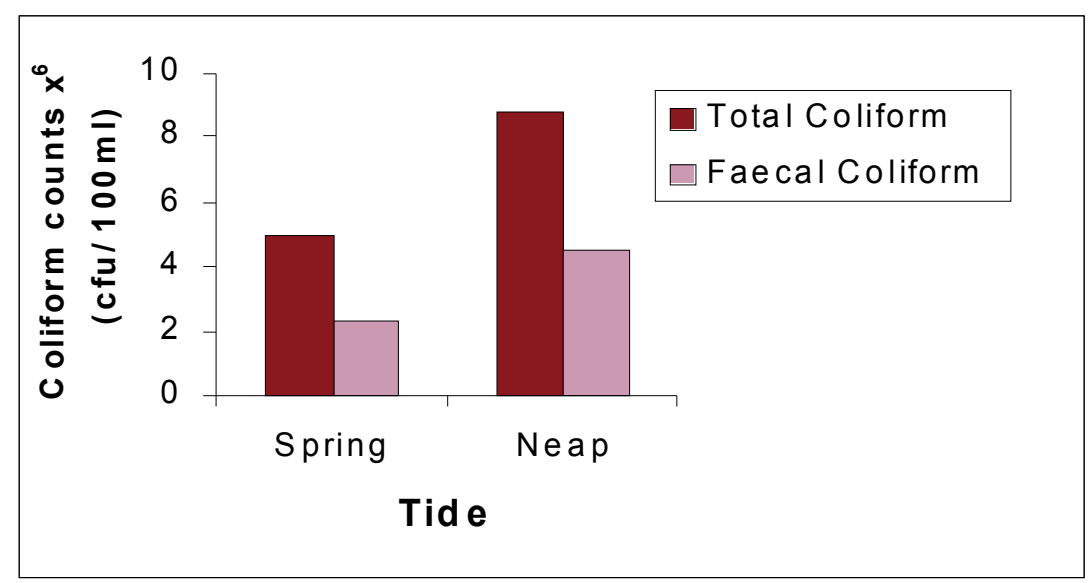

Fig. 7. Mean Coliform levels for spring and neap tides at site 5-TQ (Lagoon entrance) 


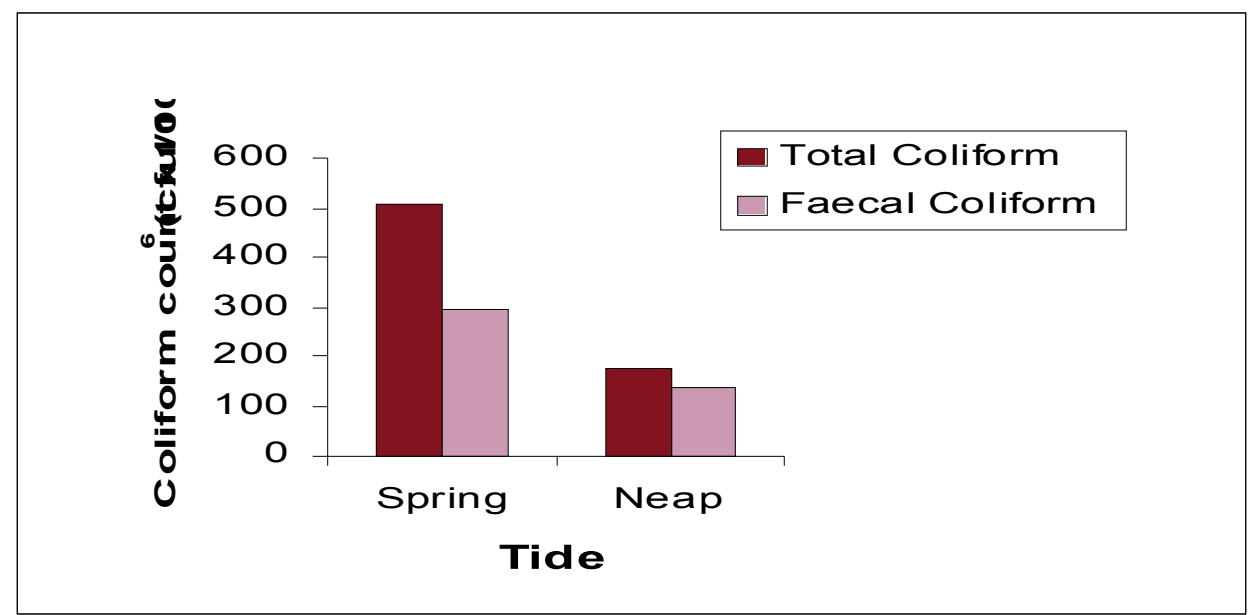

Fig. 8. Mean coliform levels for spring and neap tides at site 6-DQ Sewage outfall

\section{Physical characteristics}

Water temperatures recorded during the two sampling periods (spring and neap tides) for the outlet of the Korle lagoon did not differ significantly. Tempera-tures ranged from $31.0{ }^{\circ} \mathrm{C}$ to 33.0 ${ }^{\circ} \mathrm{C}$ with an average value of $31.8^{\circ} \mathrm{C}$ at spring tide (Table 1) while it ranged from $30.5{ }^{\circ} \mathrm{C}$ to 35.3 ${ }^{\circ} \mathrm{C}$ with a mean value of $33.0^{\circ} \mathrm{C}$ at neap tide (Table 2). The average temperatures for the sewage outfall were $33.2{ }^{\circ} \mathrm{C}$ and $31.8^{\circ} \mathrm{C}$ for the spring and neap tides, respectively. The slight variations were due to different times of sampling as the ambient temperature influenced the tempera-tures of the samples. The maximum ambient temperature at the time of sampling was $31.1^{\circ} \mathrm{C}$.

The $p \mathrm{H}$ values of the waters at the outlet of Korle lagoon were between 7.1 and 7.8 with a mean value of 7.5 for the spring tide and between 7.3 and 7.6 with a mean of 7.4 for the neap tide. These values are slightly alkaline and typical of coastal waters. The general alkaline state is partly due to the influence of seawater, which has a $p \mathrm{H}$ range of 7.5-8.4 (Riley \& Chester, 1971). The higher $p \mathrm{H}$ levels at spring tide were due to the greater influence of sea water at the highest high tide. The sewage discharge recorded characteristic $p \mathrm{H}$ values of 6.1-7.3. This compares favourably with the $p \mathrm{H}$ range of 6.45-6.96 reported by Hodgson \& Larmie (1998) from raw sewage treatment ponds at Akosombo.

From Tables 1 and 2, it can be observed that conductivity increased with salinity as expected. Higher conductivity and salinity values were recorded at spring tides when seawater intrusion was high. The mean salinity and conductivity values during spring tide were $30 \%$ and 47,667 $\mu \mathrm{S} / \mathrm{cm}$. Compara-tively, low mean levels of salinity $(15.1 \% 0)$ and conductivity $(24,100 \mu \mathrm{S} / \mathrm{cm})$ occurred at neap tide, mainly due to inflows of freshwater from inland and reduced influence of the sea water.

Relatively high DO levels were observed at different times at spring tide (highest high tides) with lower DO levels occurring at neap tide (highest low tide). DO consumption and production is influenced by plant and algal biomass, and light intensity and water temperature are subject to diurnal and seasonal variations (Connell \& Miller, 1984). Naturally, DO concentrations vary over a 24-h period due to tidal exchange. The relatively high DO levels at spring tide were attributable to the influence of wave action enriching sea water with oxygen. Low DO levels at neap tide were due to pollution from industrial and domestic sewage. Characteris-tically, the sewage discharge had very low DO levels due to high organic enrichment.

The SS levels measured for the outlet of the Korle lagoon were generally high, varying between 195-260 $\mathrm{mgl}^{-1}$ (spring tide) and 80-240 $\mathrm{mgl}^{-1}$ (neap tide). High SS were due to runoff and land-use practices, discharges of raw sewage and domestic waste, which bring large 
quantities of silt and debris into the lagoon. At high tide, the influence of particulates from the nearshore also accounted for high SS concentrations. Tidal mixing wave action cause fine sediment to resuspend, and the resulting turbidity reduces light availability for photosynthesis (Cloern, 1987). Similar results were obtained from a study at the mouth of the Chemu lagoon which recorded high SS (154 mgl$\left.l^{-1}\right)$ during high tide and $134 \mathrm{mgl}^{-1}$ at low tide (Institue of Aquatic Biology, 1996). The high SS was attributed to more turbid, particle-laden waters that enter the lagoon at high tide. It was further compounded by the direct dumping of waste, including faecal matter on the ocean front in the vicinity of the Chemu lagoon outlet.

The importance of BOD in pollution monitoring has been well established (Reish, 1972). Waters with BOD less than $3 \mathrm{mgl}^{-1}$ are known to have received no significant pollution discharges. BOD values of more than $8 \mathrm{mgl}^{-1}$ are indicative of moderate pollution (Martin, 1970) and BOD values of $12 \mathrm{mgl}^{-1}$ or more are considered grossly polluted. Based on these criteria, the mouth of the Korle lagoon could be considered moderately to grossly polluted depending on the time of sampling, the tidal changes and the release of the sewage through the outfall.

High BOD and SS concentrations were recorded at the mouth of the lagoon whenever sewage was released via the outfall. High values of BOD are indicative of excessive organic matter contained in the raw domestic and industrial effluents discharged into the lagoon. The organic matter that reached the lagoon is broken down by bacteria, which use up the dissolved oxygen in the water causing oxygen depletion, and eventually resulting in odour generation. Doe \& Pepra (1988) reported that $70-90 \%$ of the pollutants reaching the Korle lagoon were organic in nature which comprised food leftovers, paper, batteries, glass, plastics, textiles, excreta, grass, wood cuttings, aerosol cans and construction wastes.

Very high SS (Tables 1 and 2) and BOD values (Fig. 4) were recorded for the sewage discharge (outfall). The SS levels ranged from 280 to $1260 \mathrm{mgl}^{-1}$ (spring tide) and from 238 to $500 \mathrm{mgl}^{-1}$ (neap tide). The BOD values varied from 270 to $1275 \mathrm{mgl}^{-1}$ (spring tide) whereas it varied from 330 to $450 \mathrm{mgl}^{-1}$ (neap tide). Sewage strength is most often judged by its $\mathrm{BOD}_{5}$ or COD. Sewage is considered weak when the amount of biodegradable organic waste, $\mathrm{BOD}_{5}=$ 200-250 $\mathrm{mgl}^{-1}$ (Mara, 1976). Since the concentration of organic matter in the sewage discharge (outfall) adjacent to the Korle lagoon is very high, the strength of the sewage is considered as strong. The High SS and BOD values indicate severe pollution at the outfall area and, eventually, affect the mouth of the lagoon during tidal action.

Relatively high DO and low BOD levels of the offshore samples, sites 7-WQ and 9-WQ, did not indicate any severe pollution threat. The implication is that although the outlet of the lagoon and immediate environs are moderately to grossly polluted because of discharges from the sewage outfall and from inland, this negative impact is significantly reduced less than $1 \mathrm{~km}$ offshore, as a result of dilution and self purification effects of the open ocean. This process is important for artisanal fisheries, such as beach seining, which takes place within the zone less than $1 \mathrm{~km}$ from the beach.

\section{Nutrients}

The results for nitrate-nitrogen of the waters at the mouth of the lagoon during spring tide indicated generally low concentrations with a mean of $0.093 \mathrm{mgl}^{-1}$ (Fig. 3) which is below the natural background concentration of $0.25 \mathrm{mgl}^{-1}$ (Burton \& Liss, 1976). This was due to dilution with fresh sea water as indicated by offshore concentration. However, at neap tide slightly higher concentrations of nitrate occurred ranging from 0.002 to $2.30 \mathrm{mgl}^{-1}$ with a mean of $0.575 \mathrm{mgl}^{-1}$ as a result of nitrates generated from land activities such as sewage and waste from domesticated animals.

The sewage discharge nitrate-nitrogen (spring tide) varied from 0.114 to $0.300 \mathrm{mgl}^{-1}$ with an average of $0.204 \mathrm{mgl}^{-1}$ (Fig. 4). Moderate nitrate-nitrogen concentra-tions occurred at neap tide with a mean of $0.249 \mathrm{mgl}^{-1}$ (Fig. 4). The offshore areas were relatively low in nitrate-nitrogen and 
total phosphate. Nitrate-nitrogen levels of 0.078 and $0.038 \mathrm{mgl}^{-1}$, and total phosphate of 0.031 and $0.001 \mathrm{mgl}^{-1}$ occurred at sites 7-WQ and 9-WQ (Fig. 5 and 6), respectively, which suggested low pollution effect from domestic and sewage discharges due to dilution with the open sea water a few kilometres offshore. Low levels of phosphate $\left(0.05 \mathrm{mgl}^{-1}\right)$ and nitrate-nitrogen $(0.18$ $\mathrm{mgl}^{-1}$ ) were also reported by Biney (1995) in the immediate offshore waters of Sakumo II lagoon in Ghana.

Compared with nitrate-nitrogen, the corresponding ammonia-nitrogen levels were higher for all the samples during the two tides. In areas of very low DO levels such as at the entrance of the lagoon and in the area of the sewage outfall, nitrate is readily reduced to ammonia. This should account for the generally high ammonia concentrations. It was, however, observed that ammonia concentrations at neap tide (ranging between 17.7 and $33.2 \mathrm{mgl}^{-1}$ ) were higher than the spring tide (Fig. 3). Land activities such as sewage effluent, agriculture run-off as well as the sewage outfall might have contributed to the high ammonia concentration. In the tidal waters at the mouth of the lagoon, the primary source of ammonia is direct discharge from sewage outfall. High ammonia is toxic to invertebrates and fish. Acute toxicity of ammonia to fish increases with low dissolved oxygen concentrations. This has been shown in both fresh and marine environments (Seager et al., 1988; Nison et al., 1995).

The mean concentrations of total phosphate at the mouth of the lagoon were 0.232 and 0.314 $\mathrm{mgl}^{-1}$ for the neap and spring tides, respectively. The phosphate levels, though not very high, have the potential to cause eutrophica-tion. The low variation in phosphate concentrations may be the result of some buffering mechanism whereby phosphorus is released from or absorbed by the sediments depending on its concentration in the overlaying waters (Biney, 1982). High levels of nutrients in the form of total Kjeldahl nitrogen (combination of ammonia and organic nitrogen) were recorded at the mouth of the Korle lagoon. The high levels recorded were due to excessive industrial, domestic and raw sewage discharges. Estuaries may be particularly susceptible to nutrient enrichment from offshore sewage pipe outfalls (Kennish, 1992).

\section{Bacteriological analyses}

The results of the bacteriological analyses are presented in Fig. 7 and 8. The concentra-tions of total coliforms at the mouth of Korle lagoon ranged from $28 \times 10^{3}$ to $23.8 \times 10^{6}$ counts per 100 $\mathrm{ml}$ with a mean of $4.95 \times 10^{6}$ counts per $100 \mathrm{ml}$ while that of faecal coliforms varied between 13 $\times 10^{3}$ and $9.4 \times 10^{6}$ counts per $100 \mathrm{ml}$ with a mean of $2.29 \times 10^{6}$ counts per $100 \mathrm{ml}$ (spring tide). On the other hand, the total coliforms for the neap tide was higher, ranging between $2.98 \times 10^{6}$ and $20.2 \times 10^{6}$ counts per $100 \mathrm{ml}$ (mean: $8.83 \times 10^{6}$ counts per $100 \mathrm{ml}$ ) and that of the faecal coliforms ranged from $1.4 \times 10^{6}$ to $12.7 \times 10^{6}$ counts per $100 \mathrm{ml}$. The concentration of coliforms at the entrance of Korle lagoon was observed to vary with the tides. High concentrations of coliforms were recorded at neap tide, especially when the tides coincided with the discharge of the raw sewage via the outfall.

The presence of high faecal coliform counts is a sign of the extent of contamination of the waters by pathogens or disease-causing organisms. The faecal coliform levels observed at the entrance of the Korle lagoon make it unsuitable for both primary contact (such as swimming) and secondary contact, i.e. for boating and fishing, according to World Health Organisation (WHO) limits (Millipore, 1991). It indicates significant health risk to humans and other aquatic animals. Health risks include induction of illness through exposure of recreational swimmers and boaters to pathogens and consumption of undercooked or raw seafoods that have accumulated pathogens. In Ghana, for instance, enteric diseases are second to malaria in the number of cases reported in the nation's hospitals. About 400,000 cases of enteric diseases are reported annually in the country (Ministry of Health, Ghana, 1996).

Extremely high values of total and faecal coliforms occurred in the sewage outfall in both tides (Fig. 8). This could account for the high values of coliforms observed at the mouth of Korle 
lagoon since the sewage outfall is quite close to the lagoon and could be easily flushed into the lagoon by the sea at high tide. Also, defaecation in the vicinity of the lagoon could contribute to the high level of contamination. Notwithstanding, in spite of higher organic output from land, bacterial pollution of the mouth of the lagoon originates more from the seaward end of the lagoon because of the direct disposal of untreated sewage onto the beaches close to the entrance of the lagoon. It has been recom-mended that, in developing countries, the major objective of waste water treatment should be pathogen removal because of the prevalence of enteric diseases, which cause about 5 million or more deaths in children annually (UNICEF/UNDP, 1990).

\section{Conclusion}

The survey indicated that the entrance of the Korle lagoon is moderately to grossly polluted as evidenced by the physical, chemical and bacteriological characteristics. The cause can be traced to discharges of domestic and industrial effluents from inland as well as to the operations of the sewage outfall in the vicinity of the lagoon entrance. At high tide, the effluents from the outfall are back-washed into the lagoon.

The pattern of water quality changed with the tides. For example, during spring tide, high DO and low BOD levels were recorded and vice versa. At spring tide, the DO levels increased due to wave action and sea water intrusion. The raw sewage and debris flushed into the entrance of the lagoon at spring tide are retained and measured during neap tide, reflecting in high BOD and coliform levels. It was noted that the pollution at the estuary of the lagoon was greatly influenced by the tidal changes and the discharge of the sewage through the outfall.

The extremely high levels of BOD, SS, coliforms and ammonia-nitrogen of the raw sewage give an indication of the extent of organic pollutants introduced into the sea. However, the samples collected $500 \mathrm{~m}$ offshore showed good water quality. The implication is that although the outlet of the lagoon and immediate environs are moderately to grossly polluted because of discharges from the sewage outfall and from inland, this negative impact is significantly reduced less than $1 \mathrm{~km}$ offshore as a result of dilution effect of the open ocean. This process is important for artisanal fisheries, such as beach seining, which take place within the zone less than $1 \mathrm{~km}$ from the beach.

\section{Acknowledgement}

The study was undertaken as part of strategies to restore the Korle lagoon. The expertise provided by HR Wallingford of UK is hereby acknowledged. The authors also wish to thank the staff of the CSIR-Water Research Institute for their assistance during the field and laboratory analyses.

\section{References}

American Public Health Assoc. (1989). Standard Methods for the Examination of Water and Wastewater, 17th edn. Washington DC, 1193 pp.

Amoah C. M., deGraft Johnson K. A. A., Adomako J. and Nunoo F. (1998). Ecological Baseline Survey for Korle Lagoon. Department. of Botany, University of Ghana. $70 \mathrm{pp}$.

Amuzu A. T. (1995). Degradation of the Korle Lagoon. Report Prepared for Accra Sustainable Programme-City Consultacies held from 29th March to 4th April. $10 \mathrm{pp}$.

Burton J. D. and Liss P. S. (1976). Estuarine Chemistry. Academic Press, London, 229 pp.

Biney C. A. (1982). Preliminary Survey of the State of Pollution of the Coastal Environment of Ghana. Oceanol. Acta No. SP 39-43.

Biney C. A. (1995). Environmmental Baseline Studies-Limnology of Sakumo II Lagoon. Ghana Coastal Wetlands Management Project. 34 pp.

Cloern J. E. (1987). Turbidity as a Control on Phytoplankton Biomass and Productivity in Estuaries. Continental Shelf Res. 7(11/12): 1367-1381.

Connell D. W., and Miller G. J. (1984). Chemistry and Ecotoxicology of Pollution. John Wiley \& Sons, N.Y.

deGraft -Johnson K. A. A. (1991). Ecosystems and Vegetation: In Coastal Management Plan for Accra, vol. 5. Environmental Management Associates. 27 pp.

Doe K. B. and Peprah P. (1988). Problems of Waste Management in Urban Areas of Ghana. TCPD, Accra. 
Hodgson I. O. A and Larmie S. A. (1998). An Evaluation of the Treatment Efficiencies of the Sewage Treatment Ponds at Akosombo. CSIR-Water Research Institute, Accra, Ghana. WRI/CAR No. 14. 20 pp.

Institute of Aquatic Biology (1996). Status Report No. 2 on Chemu Lagoon, Tema. Consultancy Report Submitted to EPA, Ghana. $10 \mathrm{pp}$.

Kennish M. J. (1992). Ecology of Estuaries. Anthropogenic Effects. CRC Press, Inc. Boca Raton, Fl.

Mara D. (1976). Sewage Treatment in Hot Climates. John Wiley and Sons Ltd., New York.

Martin D. F. (1970). Marine Chemistry, vol. 1. Marcel Dekker, Inc., New York. 281 pp.

McClusky D.S. (1971). Ecology of Estuaries. Heineman Educational Books, London.

Millipore (1991). Water Microbiology. Laboratories and Field Procedures. Bedford, M.A. 32 pp.

Ministry of Health, Ghana (1996). Health Statistic Data of Ghana. 31 pp.

Nai G. G. (1994). Quantitative Evaluation of Pollution in the Korle lagoon. Ministry of Works and Housing, Accra. $43 \mathrm{pp}$.

Nison S. C., Gunby A., Ashley S. J., Lewis S. and Smith I. (1995). Development and Testing of General Quality Assessment Schemes; Dissolved oxygen and Ammonia in Estuaries. NRA Project Record 469/15/HO.

Reish D. J. (1972). The use of marine invertebrates as indicators of varying degrees of marine pollution In Marine and Sealife (M. Ruivo, ed.) Fishing News Books Ltd., London, England.

Riley J. P. and Chester R. (1971). Introduction to Marine Chemistry. Academic Press, London, 465 pp.

Seager J., Wolff E. W. and Cooper V. A. (1988). Proposed Environmental Quality Standard for List II Substances in Water: Ammonia. WRC Report No. TR 260.

UNICEF/UNDP (1990). The State of the Art of the Environment. 73 pp.

World Health Organisation (1987). Global Environmental Monitoring System /Water Operational Guide. WHO, Geneva, 489 pp. 